Mursalov M. M., Ph.D. (Economics), Senior Lecturer Azerbaijan State University of Economics (UNEC) Baku, Azerbaijan

DOI: https://doi.org/10.30525/978-9934-26-028-5-9

\title{
BANKING REGULATION IN THE CONTEXT OF DIGITAL REALITIES: TRENDS AND PROSPECTS
}

The late XX-early XXI centuries were a period of profound changes in banking, numerous innovations in the organization and methods of management of bank sphere. These processes, to varying 
degrees and with varying intensity, have affected all aspects of the banking regulation process, both globally and within the national framework. To determine the prospects for the development and improvement of banking regulation, it is important to assess not only existing, but also newly formed trends, to characterize them, to assess the possible consequences. Today, experts from many countries agree on the establishment of the so-called "new reality" in the emerging economy, characterized by revolutionary transformations in the markets of informatics and telecommunications, on the one hand, and in financial markets, on the other. In these conditions, the existing methods and systems of banking regulation are becoming more complicated, acquire modern features. At the same time, completely new, original forms of it are emerging, which had no analogues in world practice and became possible due to a complex combination of a number of reasons (financial crisis, technological revolution, coronavirus outbreak, etc.).

The rapid development of digital technologies leads to an unprecedented transformation of the banking industry, which is reflected in a change in the competitive environment, as well as in the process of interaction between banks and regulators. In such conditions, it is necessary to improve the traditional regulatory scheme and develop new types of effective regulatory solutions aimed at the structural development of the financial market and ensuring the stability and competitive potential of banks in the context of global technological and behavioral changes. In the economic literature, effective banking regulation is characterized, in particular, by the optimal level of regulatory burden, which shows how burdensome it is for financial institutions to comply with the measures established by the regulator [1, p. 8]. It is important to understand that an increase in this burden is, as a rule, a consequence of improving regulatory measures aimed at ensuring the sustainable functioning of financial institutions. Therefore, it is advisable to talk not about its minimization, but namely about achieving and maintaining the optimal level. 
Traditional business models based on the production of universal banking products are being replaced by models based on consumer needs. By influencing the supply, the consumer also becomes the driving force behind the competition. In addition, the external transformation impetus for traditional banks is the growing competitive threat from non-bank financial service providers (big and fintech, tech and telecommunications companies). So, today non-banking institutions provide services in the field of payments (Google, Amazon, Apple, Facebook, Samsung), lending (Baidu, M-Pesa, eBay, Google, Orange), insurance and money market funds (Alibaba, Tencent, Baidu , Grab). Some of these companies can carry out a full range of essentially banking operations [2, p. 57]. The result of comparing the services of JP Morgan \& Chase with those of Amazon shows that almost all of the bank's services have an equivalent in Amazon [3, pp. 16, 33-34, 45]. According to foreign experts, bigtechs are involved in the financial services industry with a loyal customer base, and the high level of interconnection between financial services and the main non-financial activities allows achieving competitive advantages and financial benefits due to economies of scale [2, p. 61; 4, p. 5].

Transformational changes provide a number of benefits, but at the same time are associated with new risks (at the micro level and systemic) that require a regulatory response. The widespread adoption of new business models among nonbank technology companies can lead to significant transformation and the emergence of new sources of systemic risk that cannot be addressed by standard prudential instruments. Probably, in the future, the revision will require a classification of risks and approaches to their management. In particular, operational and cyber risks that are currently considered specific can be considered systematic [5, pp. 34-35]. The potential negative impact of digital transformation processes on the stability of traditional banking institutions can be significantly mitigated by streamlining their management by regulatory instruments.

In the context of the interest of financial regulators in the development of financial innovation and the introduction of more 
effective regulatory systems, one of the new directions is the formation of a new approach to data-driven regulation. The basis for the formation of this approach was the expansion of the use of regulatory technologies (Regtech) from the perspective of both monitoring digital transformation and responding to internal operational tasks [6, p. 10-11]. Financial regulators of a number of countries, in particular, Canada, Great Britain, Singapore, India and Australia have already announced their readiness to use Regtech $[7$, p. 7,12$]$.

In the context of managing the digital transformation process consulting company Deloitte distinguishes three roles for financial regulators. The first is consistent with their function as a coordinator who plays a proactive role to foster innovation and competition in financial markets. At the same time, its main characteristics of a coordinator are regulatory flexibility and regulatory ecosystem. It is assumed that in this case, banks are able to effectively manage the risks associated with financial technology. The second is related to a deterrent, the role of which is to respond to emerging challenges and eliminate gaps and inconsistencies in regulatory requirements. Limiting risks can lead to a decrease in the depth and breadth of application of financial innovations. The third is the advisory role of financial regulators, increasing which will further improve this process [8, pp. 5-6]. The most optimal is the combination of the named elements of the three named roles, since each of them allows solving strictly specific aspects of banking regulation.

At the current stage of the digital transformation of the banking industry, a transformation of the role of the regulator and the development of fundamentally new approaches to regulating the activities of financial market participants (both traditional and new, whose activities go beyond the boundaries of banking services) are required. At the same time, closer interaction of the regulator and supervised organizations is needed, as well as an increase in the adaptability and predictability of regulation, clarification of approaches to the process of banking regulation, taking into account sectoral and digital challenges [9, pp. 19-49]. 
Taking into account the above, in order to increase the efficiency of the banking regulation system, it seems appropriate to implement the following measures:

- identification of obsolete and overlapping regulatory norms;

- development of approaches that ensure the development of partnerships by banks and their expansion of the range of available banking operations;

- improving the manufacturability of regulation and expanding the use of regulatory and supervisory technologies by the regulators themselves.

The proposed measures will contribute to the improvement of the banking regulation system in the context of digital transformation, the objective perception by regulators of digital realities and the development of adequate solutions to respond to them, and ultimately the achievement of a balance between stimulating innovation, protecting the rights of consumers of banking services and ensuring financial stability.

\section{References:}

1. Golodnikova A.E., Efremov A.A., Sobol D.V. et al. (2018) Regulatory Policy in Russia: Main Trends and Architecture of the Future. Moscow: High School of Economics, 192 p. (in Russian)

2. Big tech in finance: opportunities and risks (pp. 55-79). BIS Annual Economic Report 2019. Basel: Bank for International Settlements, June 2019, xiv, 79 p. URL: https://www.bis.org/publ/arpdf/ar2019e.pdf.

3. Everything You Need to Know about What Amazon is Doing in Financial Services. New York: CB Insights. 2020. 49 p. URL: https://www.cbinsights.com/ research/report/ amazon-across-financial-services-fintech.

4. Yuzefalchik I. Improvement mechanisms financial regulation in digital transformations. Bank Bulletin Journal. Minsk: The National Bank of the Republic of Belarus, pp. 3-14.

5. Implications of fintech developments for banks and bank supervisors. Basel: Bank for International Settlements, February 2018, 49 p. URL: https://www.bis.org/ bcbs/publ/ d431.pdf.

6. Treleaven P. (2015) Financial Regulation of Fintech. The Journal of Financial Perspectives: Fintech. EY Global Financial Services Instituten, vol. 3 (3), pp. 114-121. URL: https://www.eycom.ch/en/Publications/20160309-The-Journal-ofFinancial-Perspectives-Winter-2015-FinTech/download. 
7. Podder S., Pisanu G., Ghosh B. et al. (2018) Regtech for regulators. Rearchitect the system for better regulation. World Government Summit. February, 2018, 33 p. URL: https://www.worldgovernmentsummit.org/api/ publications/document ?id=5ccf8ac4-e97c-6578-b2f8-ff0000a7ddb6.

8. Brennan S., Dobra-Kiel A. (2019) Digital transformation meets regulation 4.0 in 2030. Part 1/3: Coping with disruptive innovation. London: Deloitte LLP, 7 p. URL: https://www2.deloitte.com/content/dam/Deloitte/uk/Documents/financial-services/deloitte-uk-digital-transformation-meets-regulation-part1.pdf.

9. Global Financial Development Report 2019/2020: Bank Regulation and Supervision a Decade after the Global Financial Crisis. Washington, DC: World Bank Group, 2020, xvi, 136 p. 